\title{
JUURNAL.RU
}

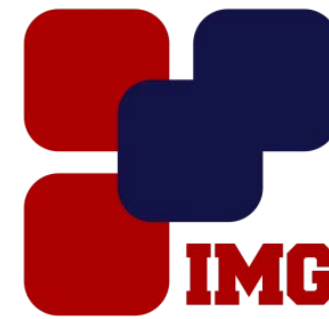

Iyanoy
Management
GRoup

Акбашева Д. М., Хубиева М.Н. Северо-Кавказская Государственная Гуманитарно-Технологическая Академия Черкесск, Россия

doi: 10.18411/lj-25-12-2016-3-05

idsp 000001:lj-25-12-2016-3-05

\section{Учет затрат по автотранспорту}

\section{Аннотация}

Затраты на содержание и эксплуатацию транспортных средств зачастую составляют весьма значительную часть текущих расходов организации. Такие расходы участвуют в формировании себестоимости продукции (работ, услуг) организации, при условии что они экономически обоснованны и подтверждены документально. Рассмотрим особенности учета отдельных видов расходов, связанных с использованием автотранспорта.

Ни одно предприятие, как правило, не обходится в своей деятельности без автотранспортных средств - собственных или арендованных. В связи с этим актуальными являются вопросы учета затрат на их содержание и эксплуатацию. В этой статье мы не стали затрагивать вопросы учета расходов на медицинский осмотр водителей и на страхование транспорта.

Основные расходы организации на содержание служебного автотранспорта:

- материальные (топливо, смазочные материалы);

- ремонт автотранспорта.

Для целей бухгалтерского учета расходы на приобретение топлива и смазочных материалов для служебного автотранспорта относятся к расходам по обычным видам деятельности (ПБУ 10/99 «Расходы организации»).

Оплата поставщикам топлива может производиться наличным и безналичным путем. Приобретение топлива водителями за счет подотчетных средств требует оформления авансового отчета.

Топливо и смазочные материалы принимаются к бухгалтерскому учету по фактической себестоимости по дебету счета 10 «Материалы» (субсчет 10-3 «Топливо») в корреспонденции со счетами учета расчетов (счет 60 «Расчеты с поставщиками и подрядчиками», 71 «Расчеты с подотчетными лицами» и др.).

Топливо и смазочные материалы списываются на производственные и управленческие нужды на основании первичных расходных документов (ведомостей учета выдачи нефтепродуктов, требований, накладных, путевых листов и т. д.) и отражается по кредиту счета 10 «Материалы» (субсчет 3) в корреспонденции с дебетом счетов учета затрат на производство $(20,23,25,26$, 
44). Приведем типовые бухгалтерские проводки по операциям на содержание служебного автотранспорта:

Дт 10-3 - Кт 60 - Отражена стоимость приобретенных ГСМ согласно расчетным документам поставщика (без учета НДС)

Дт 19-3 - Кт 60 - Отражена сумма НДС, предъявленная поставщиком ГСМ

Дт 60 - Кт 51 - Произведена оплата поставщику

Дт 68-1- Кт 19.3 - Предъявлена к вычету сумма НДС, уплаченная по принятому к учету топливу

Дт 20, 26, 44 - Кт10-3 - Списано топливо на производственные или управленческие нужды согласно данным путевых листов

Расходы на топливо для автотранспортных средств включаются в состав материальных затрат в расходах по обычным видам деятельности в пределах норм, утверждаемых Минтрансом России, что указывается в учетной политике организации. Об этом говорится в Приказе Минтранса РФ от 24.06 .03 №153 "Об утверждении Инструкции по учету доходов и расходов по обычным видам деятельности на автомобильном транспорте". Нормы расхода топлива установлены Распоряжением Минтранса РФ от 14.03.08 №AM-23-р.

Контроль за расходованием топлива следует вести в путевых листах, унифицированные формы которых установлены постановлением Госкомстата России от 28.11.97 №78 (форма №3 «Путевой лист легкового автомобиля», форма №4-С «Путевой лист грузового автомобиля», форма №6 «Путевой лист автобуса» и т. д.). Этот же документ является основанием для списания использованного топлива в расходы. В Письме Минфина РФ от 25.08.09 №03-03-06/2/161 чиновники разрешили организациям самостоятельно разрабатывать путевые листы, являющиеся документами, подтверждающими расходы на приобретение горюче-смазочных материалов. Главное условие - наличие в документе обязательных реквизитов, утв. Приказом Минтранса России от 18.09.08 №152.

Для целей налогового учета затраты на ГСМ могут учитываться при условии, что они экономически обоснованы, документально подтверждены и направлены на получение прибыли (п. 1 ст. 252 Налогового кодекса РФ).

Для целей налогообложения налогом на прибыль затраты на приобретение ГСМ и содержание служебного автотранспорта учитываются как прочие расходы, связанные с производством и реализацией (подп. 11 п. 1 ст. 264 НК РФ).

При этом хотя Налоговым кодеком не определено нормирование указанных расходов, финансисты требуют включать состав расходов сумма затрат на топливо для служебных поездок в пределах норм расхода, установленных Распоряжением Минтранса РФ от 14.03.08 №AM-23-р.

Начисление компенсаций за использование личных легковых автомобилей для служебных поездок отражается в учете по дебету счета 26 «Общехозяйственные расходы» и кредиту счета 73 «Расчеты с персоналом по прочим операциям». 


\section{Литература}

1. Бухгалтерский учет и анализ: учебное пособие / под ред. Е. И. Костюкова. - Москва: Кнорус, 2014. - 405 с.

2. Бухгалтерский учет и анализ: учебное пособие / под ред. Л. И. Ерохиной. - Москва: Форум: ИНФРА-М, 2014. - 495 с.

3. Бухгалтерский учет: учебник / под ред. В.Г. Гетьмана. - Москва: ИНФРА-М, 2013. - 715 с. 